\title{
O soldado Luís Gonzaga das Virgens
}

\author{
LUÍS HENRIQUE DIAS TAVARES
}

$\mathrm{E}$ STE TRABALHO É O SEgUINTE: primeiro examino o período conhecido da vida de um soldado brasileiro no exército colonial português na capitania da Bahia. Chamou-se Luís Gonzaga das Virgens, mas ele próprio também se identificou como Luís Gonzaga das Virgens e Veiga. Depois faço a leitura dos papéis manuscritos e impressos apreendidos pelas autoridades coloniais onde ele residia até as primeiras horas do dia em que foi preso sob a acusação de ser o autor e divulgador dos "papeis sediciozos" (assim foram denominados pelas autoridades coloniais e assim passaram para a História do Brasil) que apareceram colados, a 12 de agosto de 1798, em prédios localizados em ruas de passagem obrigatória para centenas de habitantes da cidade do Salvador da última década do século XVIII, e de duas cartas deixadas na igreja da Lapa e no convento dos carmelitas descalços a 22 do mesmo mês e ano.

O tempo documentado de sua existência cobre 18 anos. Vai do alistamento como soldado voluntário na tropa paga ou regular (1781) quando tinha 20 anos de idade, até o seu sacrifício na praça da Piedade, onde foi enforcado e esquartejado a 8 de novembro de 1799 .

Os papéis examinados foram: o caderno manuscrito denominado Series Temporais, Reflectivas e Noticiozas (1); petições, requerimentos, atestados de boa conduta e cartas (2); receitas de remédios (3); orações e máximas (4); questões gramaticais e significados de palavras (5); um soneto de louvação ao governador dom Fernando José de Portugal (6); e cópias de cinco documentos que circularam na cidade do Salvador e possivelmente até em alguns engenhos do recôncavo (São Francisco do Conde e Santo Amaro da Purificação): Fala de Boissy d'Ánglas, Orador dos Estados Gerais, Aviso de Petsburgo (como está no original existente no Arquivo Público do Estado da Bahia), trechos de um capítulo de As ruinas, o famoso livro do conde de Volney, e a Gazeta de Lisboa de 25 de agosto e 10 de outubro de 1797 (7).

O soldado Luís Gonzaga das Virgens inaugura-se na História do Brasil ao ser preso, no início da tarde de 23 de agosto de 1798, nas manobras do 
$10^{\circ}$ regimento de granadeiros, no Campo Santo (atual praça 2 de Julho ou Campo Grande), segundo a versão do soldado Romão Pinheiro, ou no quartel do regimento, diretamente pelo seu comandante, coronel Antonio José de Sousa Portugal, conforme o declarado no primeiro interrogatório a que respondeu perante o Ouvidor Geral do Crime e Intendente de Polícia, o desembargador do Tribunal da Relação na Bahia, Manuel de Magalhães Pinto Avelar de Barbedo, oito dias após a sua prisão (8). Desdobravase assim a devassa ordenada pelo governador em portaria assinada no mesmo dia da divulgação dos "papeis sediciozos", e por isso destinada a identificar os seus "autores" (9).

Já era então conhecido das autoridades coloniais na capitania da Bahia por ter desertado do exército três vezes e respondido Conselho de Guerra em processo verbal instalado a 9 de abril de 1793 no quartel onde servia e estava preso (10).

Três deserções; faltas graves, que eram punidas severamente. A primeira ocorreu em 30 de outubro de 1786, voltando ao quartel em 17 de dezembro de 1790. Quatro anos de ausência! Tornou a desertar cinco dias depois. De volta ao quartel em 22 de abril de 1791 (essa segunda deserção, a mais curta das três, é de apenas quatro meses). Deserta de novo a 30 do mesmo mês e ano, sendo preso a 31 de julho de 1792, mais de um ano depois, na vila de Nossa Senhora do Rosário da Cachoeira, boca para o alto sertão.

Perdoado das duas primeiras deserções pelo governador, que incluiu o seu nome na lista de indultados na passagem de datas religiosas (nascimento de Cristo e Semana Santa), nada indicava que as piedosas práticas religiosas o levariam a novo perdão. Agora, após meses de espera na prisão, ia ser julgado.

O Conselho de Guerra reuniu-se sob a presidência do capitão José Soares Nogueira, composto dos inquiridores e vogais, efetivos e suplentes, determinados pela legislação militar portuguesa da época. Ouviu três soldados que o conheciam e testemunharam "pelo ver, e presenciar" que ele já desertara três vezes. Examinado o Livro Mestre do $10^{\circ}$ Regimento, revelou que o soldado Luís Gonzaga das Virgens sentara praça a 26 de agosto de 1781 e jurara bandeira a 31 daquele mês e ano. Ao ser julgado, estaria, portanto, com 32 anos (ele disse: "pouco mais, ou menos"), o que o coloca nascido em 1761 ou 1762, na freguesia do Pilar.

Na ocasião do julgamento foi descrito como homem pardo, de cabelos e olhos castanhos escuros. Parece-me relevante acentuar que se identificou como Luís Gonzaga das Virgens, filho do alfaiate solteiro Joaquim 
da Cunha. Na continuidade formal de um processo que só desejava caracterizá-lo como desertor, daí talvez o motivo de não ter sido indagado como desertara e o que fizera durante as deserções, confirmou ter recebido os soldos, pão (quer dizer: alimentos) e fardamentos a que tinha direito, embora já vencidos; que fora preso por ter desertado, não encontrando motivo para justificar-se, sabendo também não ter defesa (11).

Também acentuo que assinou Luís Gonzaga das Virgens no final do processo, assinatura que viria a reconhecer como sua quando da devassa presidida pelo desembargador Barbedo. E por isso o Ouvidor do Crime a transformou em "prova”, e o reconhecimento dela, em "confissão" de que ele era o autor dos papéis de 12 de agosto e das cartas de 22 (12).

O Conselho de Guerra o condenou a seis anos de trabalho forçado nas fortificações da cidade, conforme dispunha o artigo 14 do capítulo 26 do regulamento militar. Mas ele não cumpriu a pena. Seu nome aparece seis meses depois de condenado na lista de soldados indultados nas comemorações pelo nascimento da princesa da Beira (13). Depois do indulto,

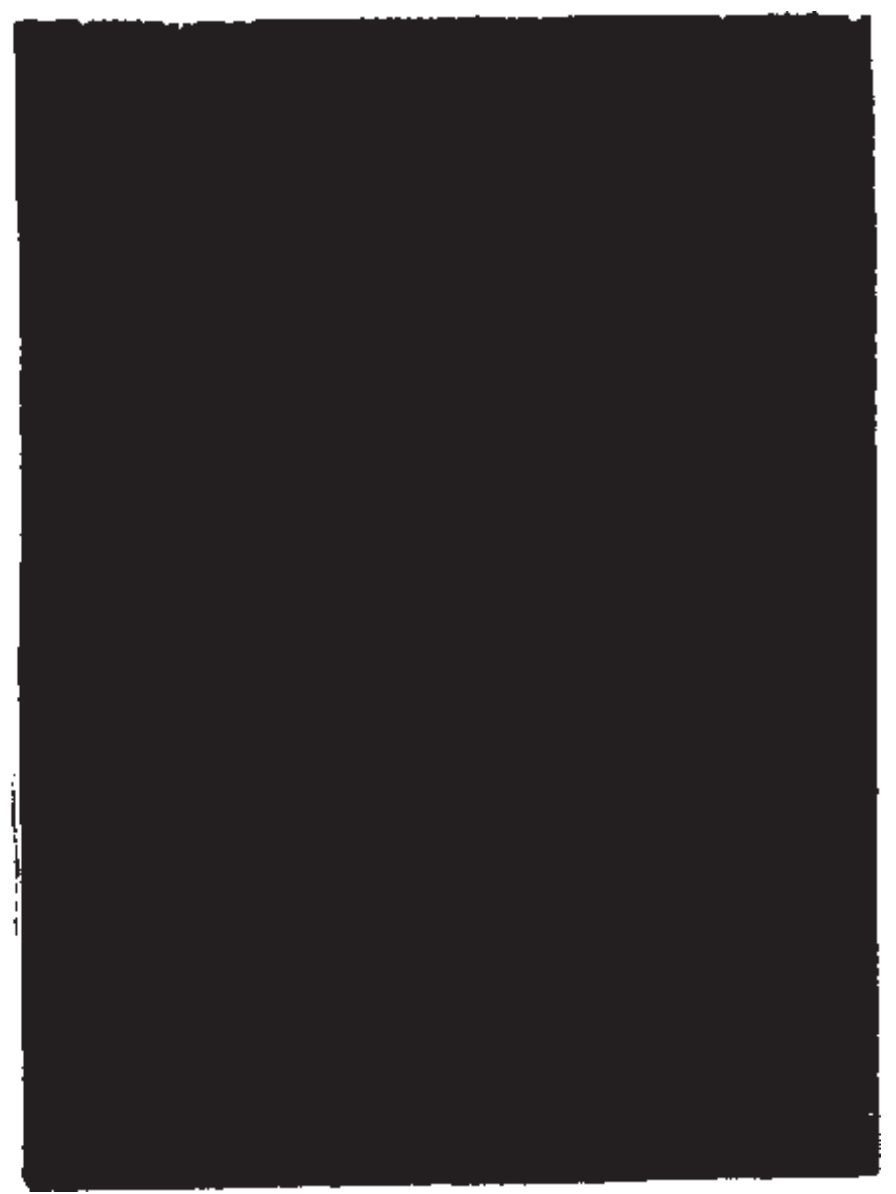


voltou para a $4^{\text {a }}$ Companhia do $10^{\circ}$ Regimento, o que significou a volta para as atividades normais de soldado (revistas pela manhã e à noite, manobras à tarde, guarda nas diversas guaritas da cidade etc.), rotina que o deixava "agoniado e capaz de morrer", conforme queixa testemunhada pelo escravo José Félix da Costa.

Há mais sobre as deserções nas respostas às perguntas no primeiro interrogatório após a sua prisão. São igualmente imprecisas quanto às deserções, mas não será por isso que deixam de ser extremamente importantes, pois foi nessa altura que o soldado Luís Gonzaga introduziu o personagem a quem responsabilizou pela autoria de todos os papéis que lhe apresentaram como escritos por ele, apenas confirmando que lhe ditara alguns: os que pareciam mais irrecorrivelmente seus.

Até agora não identificado, esse anônimo seria, pelo que Luís Gonzaga declarou, um branco, português, cirurgião prático e negociante de gado. Disse que o conheceu pelo nome de Manuel João, mas depois de algum relacionamento com ele veio a saber que o seu nome verdadeiro era João da Silva Norbona.

Ele o teria encontrado na vila do Rio Grande do Norte em 1791 ou 1792 ("a seis ou sete anos", disse nesse interrogatório), no decurso da terceira deserção, que durou pouco mais de um ano. Indo por aí, pode-se especular, todavia sem base na documentação, que ao desertar em abril de 1791 varou os sertões de Bahia, Pernambuco, Paraíba, e Ceará, alcançando então a capitania subalterna do Rio Grande do Norte. Só não se sabe como realizou essa proeza, porque uma tal viagem se tratava realmente de proeza não pequena naquela época (e até muito depois), mas sabe-se ao menos, visto que ele o disse, ter regressado para a Bahia tangendo gado em companhia desse até agora desconhecido João da Silva Norbona (14).

Ele o descreveu para o desembargador Barbedo: um "homem alto, de grossura ordinária, vermelho de cara, cabelo claro feito de chicote curto, com huma cicatriz no canto da face direita, vestido quase sempre com vestido de panno azul, calção de pagem, chapeo redondo, diferentes chinelos nos pés, sem espada, trançado ou bengala" (15). Continuou informando que esse Norbona era português nascido na cidade do Porto, muito instruído e informado dos acontecimentos na Europa pelo que lia nos jornais, em especial sobre "a situação" na França e na Inglaterra, "discorrendo sobre a igualdade dos homens e humanidade com que deviam ser tratados, principalmente sobre a injustiça de não serem admitidos os homens pardos" (16). 

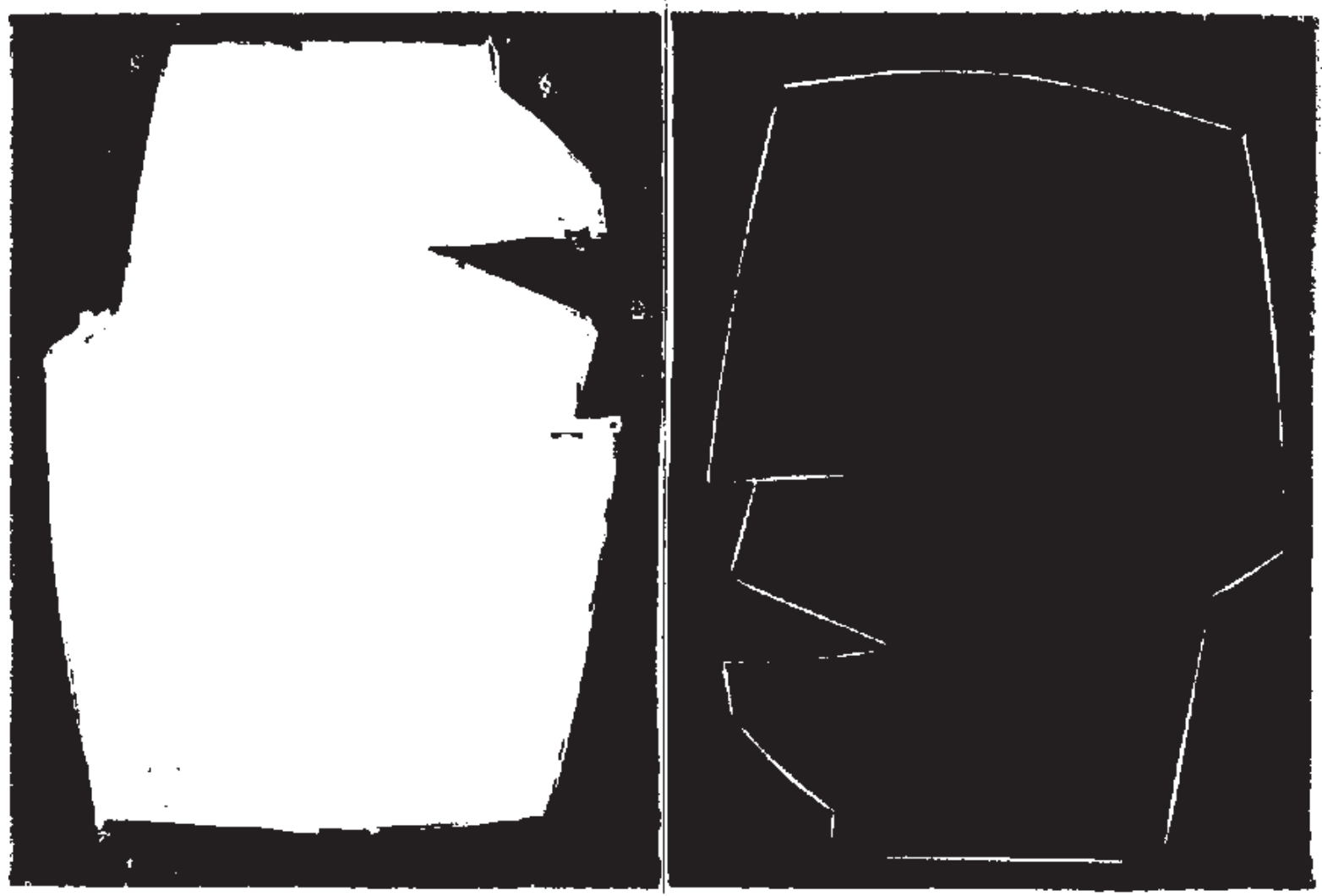

Apenas um ano e pouco (abril de 1791 a julho de 1792) para tanto conhecimento e entendimento com um homem branco, português e mascate, além do mais cirurgião prático, sendo ele, Luís Gonzaga das Virgens, um soldado desertor e mestiço! Interrogado, porém, a 6 de março de 1799, sete meses depois do último interrogatório em 1798, e agora sob a urgência de conclusão da devassa, exigida pelo príncipe regente dom João em correspondência de 22 de dezembro de 1798, Luís Gonzaga acrescentou novos detalhes sobre os seus períodos de desertor e episódios subseqüentes ao Conselho de Guerra, o indulto e a volta para o quartel (17). Disse então que "a sua comunicação com Manuel João" começara "a seis para sete anos", "contudo ao certo não se lembrava o tempo fixo que havia com elle principiado a dita comunicação, por quanto elle o conhecera por espaço de quatro Pascoas" (ou seja: quatro anos) (18).

Portanto, destaco: ele declarou que o conheceu durante quatro anos. Tal informação permite supor que o encontro com esse mascate e cirurgião prático português ocorreu no primeiro tempo de desertor, por sinal o mais longo: 1786-1790. Só não há como documentar, e é por isso que fica neste texto apenas como suposição. Talvez um dia a pesquisa histórica consiga esclarecer. Seja, porém, nos quatro anos da primeira deserção, ou seja no ano e pouco da terceira, acredito que ao menos é possível fixar que o 
soldado Luís Gonzaga das Virgens conheceu por aquele tempo um alguém que o influenciou com palavras e escritos, falando-lhe da revolução francesa e da idéia de igualdade, dessa principalmente, a mais viva para ele, por causa da realidade de sua vida de homem de cor, e pelo que sentia e via das restrições que sofriam os seus iguais, todos, como ele, filhos ou netos de escravas africanas ou crioulas, ou seja: homens de cor.

Além dos pedaços como desertor, outro fato marcante da vida do soldado Luís Gonzaga foi a busca da herança do avô materno, o português Manuel Gomes Veiga, falecido com registro de testamento em 1794. Vale lembrar que ao se alistar na tropa paga ele se qualificou como Luís Gonzaga das Virgens, filho do alfaiate solteiro Joaquim da Cunha. Repetiu o mesmo no Conselho de Guerra. Mas em 1795 ou 1796, talvez mais em 1796, o ano de sua "reforma", ele mudou essa identidade e passou a se apresentar como Luís Gonzaga das Virgens e Veiga, filho legítimo do capitão de milícia Joaquim da Cunha Rubim (ou Rubi, como também aparece grafado) e de Rita Gomes Veiga, ambos já falecidos. É assim que se apresenta no primeiro interrogatório da devassa sobre os "papeis sediciozos" (19). Por que deixa de se qualificar como anteriormente, filho do alfaiate solteiro Joaquim da Cunha, e passa a se afirmar filho legítimo do capitão de milícia Joaquim da Cunha Rubim, a quem, por sinal, disse não ter conhecido, e da “crioula forra" Rita Gomes Veiga (20)?

Aceite-se, na falta de resposta autorizada pela documentação, que naquela cidade do Salvador duramente escravista e totalmente carregada de preconceitos de cor (ela assim se manteve ao longo do século XIX e ainda assim se mantém neste século XX) havia profunda diferença social em ser filho de um alfaiate solteiro e ser filho legítimo de um capitão de milícia casado legalmente com filha de branco, ademais português falecido com testamento registrado. Por certo valia socialmente mais ter Veiga no sobrenome que o simples e comum das Virgens...

Está nas Series temporais, escrito ou ditado por ele: "Principiei a reforma de minha vida em 22 de junho de 1796". E na linha seguinte: "Fiz confissão geral” (21).

Já então acrescentara Veiga à sua assinatura, conforme está na cartapetição ao cadete Francisco Leonardo Carneiro da Rocha da Silva Menezes Boão (22). É igualmente como Luís Gonzaga das Virgens e Veiga que aparece no atestado de boa conduta militar assinado por alguém não menor que o comandante do seu Regimento, o coronel Antonio José de Sousa Portugal (23). Ao que deduzo, colocara sobre a sua condição de soldado pobre e mestiço uma nova e orgulhosa convicção, a de filho legitimo de 
pais “legitimamente” casados, em destaque para sua mãe, Rita Gomes Veiga, por quem poderia ter acesso à herança de Manuel Gomes Veiga, português da freguesia de São Pedro do Escudeiro, mas falecido na cidade do Salvador em mês e dia desconhecidos de 1794.

É provável que tenha sido pela certeza de suas possibilidades na herança que requereu ao escrivão da Provedoria das Fazendas, dos Defuntos e Ausentes, Capelas e Resíduos, Miguel Francisco Teles, que revisse nos livros e assentos o que havia no registro do testamento de Manuel Gomes Veiga e atestasse a "legitima” de Rita Gomes Veiga, juntamente declarando "dividas activas e passivas mencionadas no referido theor da verba supra” (24).

Verificou então que Manuel Gomes Veiga realmente atestara (e testara) deixar três filhos: Rita, filha de sua escrava Elena; Calisto e Maria da Encarnação Gomes, casada, filhos de sua escrava crioula Inácia. Herdavam partes iguais, existindo, porém, outros herdeiros, sobrinhos de Manuel Gomes Veiga e moradores em São Pedro do Escudeiro. Nada havia, no entanto, para comprovar que a Rita referida no registro de testamento de Manuel Gomes Veiga era a mesma Rita Gomes Veiga casada com Joaquim da Cunha Rubim e mãe de um filho homem. Daí resultou que o soldado Luís Gonzaga das Virgens e Veiga não teve como provar o seu direito àquela herança. Mesmo assim ainda fez uma tentativa de legitimação requerendo a sua certidão de batismo, com os nomes dos padrinhos, ao deão provedor da matriz do Pilar, que todavia a deixou sem resposta (25).

A partir daí quase não existem informações. Mas é preciso registrar que em dezembro de 1797 está no batizado da filha do soldado e marceneiro Lucas Dantas do Amorim Torres, outro dos quatro supliciados a 8 de novembro de 1799. Por causa do atraso de Manuel Faustino dos Santos Lira, que era o convidado para ser o padrinho da criança, ele quase o substitui, uma demonstração de estima e consideração no ritual baiano. Só não foi o padrinho porque Santos Lira ainda chegou a tempo na igreja. Mas ele ficou para a ceia, na qual também esteve presente o tenente Hermógenes Francisco de Aguillar Pantoja, militar brasileiro que seria preso em fevereiro de 1799 sob suspeita de participar da sedição (26).

No início de agosto de 1798 há o episódio na guarita da Praia, ocasião em que Lucas Dantas lhe repetiu e comentou um papel deixado em açougue próximo protestando contra o aumento do preço da carne. Teriam bebido aguardente e brindado ao "levante" (27). Poucos dias após, a 12 de agosto, aparecem os "papeis sediciozos". A 23, o soldado Luís Gonzaga é preso e levado à presença de dom Fernando José de Portugal (de todos os presos, foi o único conduzido até o governador, detalhe expressivo, 
mas ainda não examinado). É então acusado da autoria e divulgação daqueles papéis $(28)$.

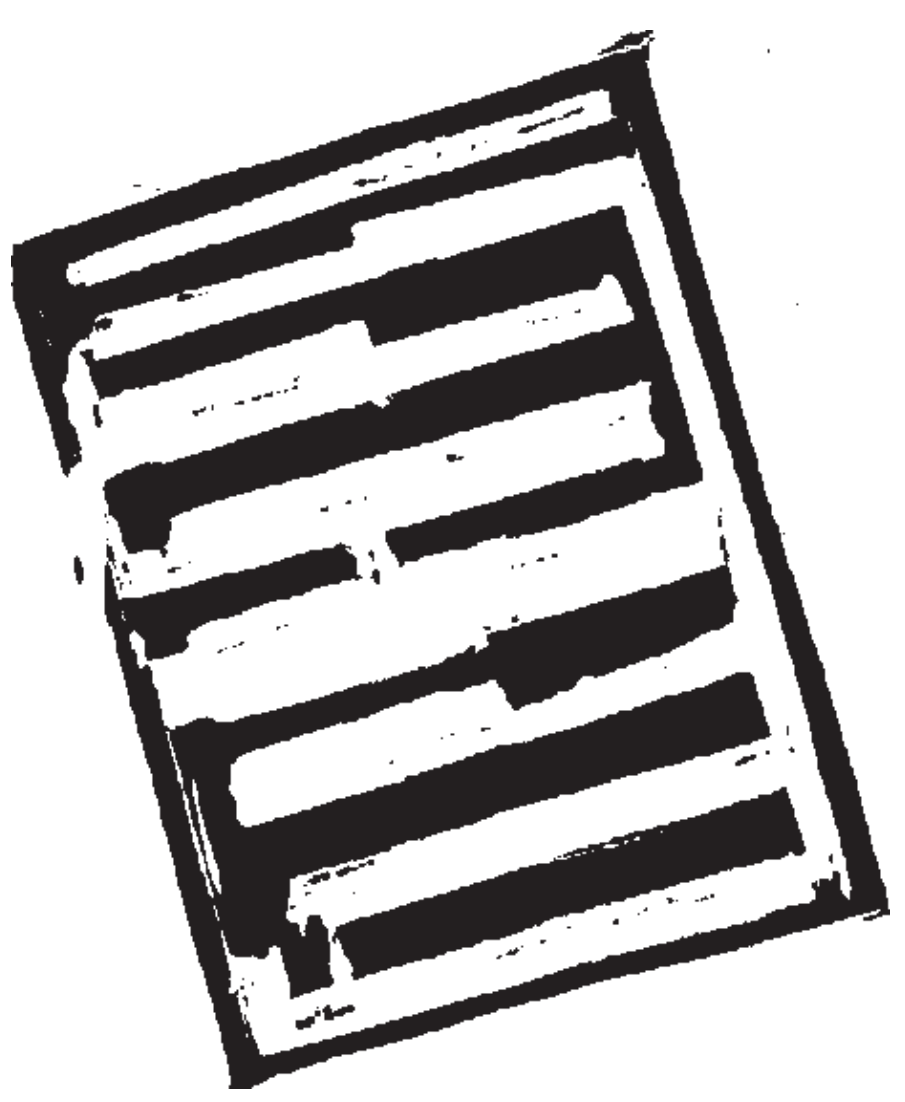

No interrogatório a que respondeu a 18 de setembro, ainda com enorme corte na testa, da cutilada que recebeu ao resistir à prisão, Lucas Dantas declarou que Luís Gonzaga o convidara para "huma revolução", dizendo-lhe também que tinha muitos soldados do seu regimento "prontos a aderir" (29). Depois dos "papeis sediciozos", em novo encontro com Lucas Dantas teria demonstrado "grande prazer e regozijo" pela divulgação deles e dito que eram "hum excelente meio de conseguir a projectada revolução porque assim se alegrarão os povos" e iriam "a pouco e pouco acostumando-se a estas ideias de liberdade e independência” (30).

Por causa dessas declarações de Lucas Dantas, agravadas pelas que foram feitas por Santos Lira, João de Deus e Romão Pinheiro, sou levado a aceitar que no segundo semestre de 1797, ou no primeiro de 1798, Luís Gonzaga encontrou o movimento de rebeldia social de soldados, artesãos e escravos que desejavam igualdade de direitos, sem diferenças de cor. E esse, por sua vez, bordejou próximo do movimento político e anticolonial 
de militares, intelectuais, donos de engenhos, plantadores de cana e de fumo, e comerciantes desejosos de liberdade de comércio, que vinha se desdobrando na capitania da Bahia desde algum tempo (a partir de 1794?), sob a influência da implantação da república na França, das contradições internas da Viradeira em Portugal e das circunstâncias da guerra na Europa. A propósito da atuação e posição que nele teria o soldado Luís Gonzaga, chamo atenção para o que ocorre logo após a notícia de sua prisão.

Às primeiras notícias, alguns dos que seriam presos sob suspeita de envolvimento com a sedição em levedura, "levante e revolução", na cidade, encontraram-se na oficina do oficial lavrante Luís Pires (não teria sido o primeiro naquele local) e decidiram fazer uma reunião no Campo do Dique do Desterro, para verificarem se possuíam armas e homens em número suficiente para libertá-lo, e, se possível, começar o levante. Luís Pires teria se dirigido aos presentes (Lucas Dantas, Santos Lira, João de Deus, Nicolau de Andrade e José de Freitas Sacota) dizendo que "tinha sido preso o amigo, e patricio Luís Gonzaga das Virgens", e que não "ficava bem a todos dispostos para aquella projectada ação deixar de por logo mãos a ella" (31).

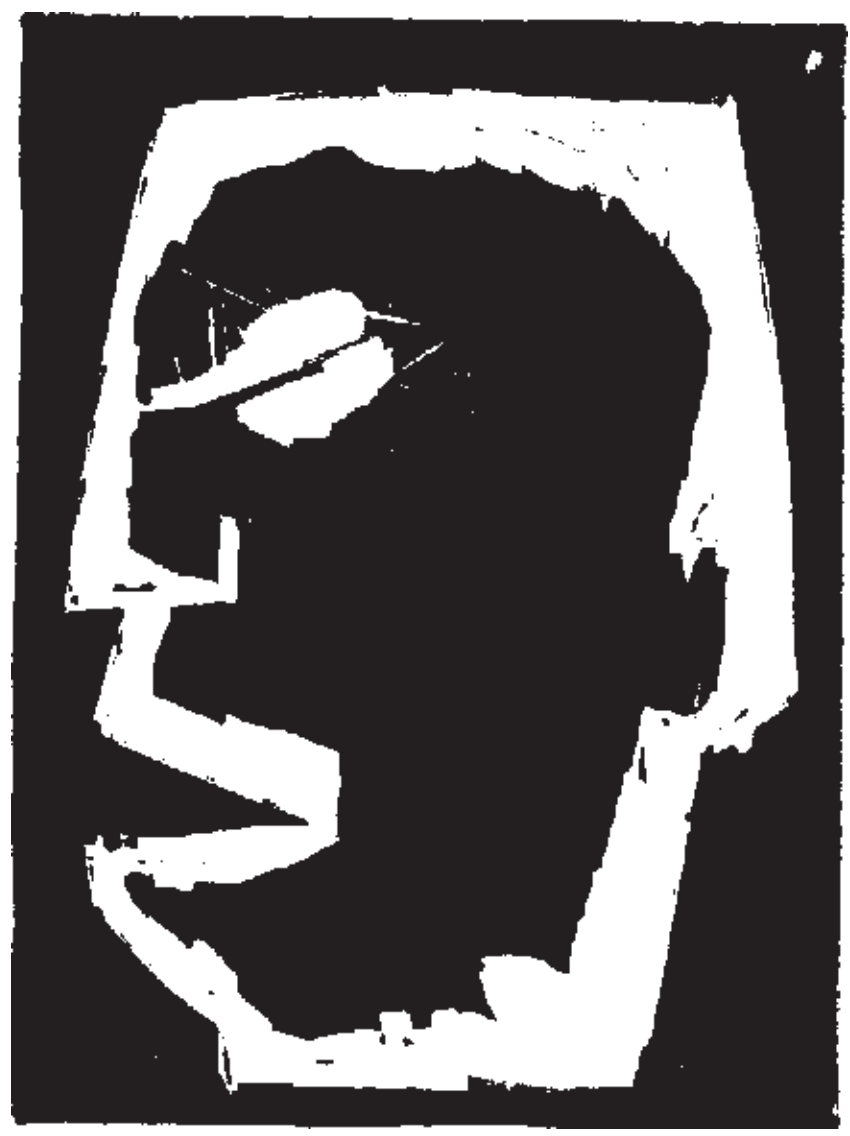


Outros reconheceram a letra do soldado Luís Gonzaga nos papéis de 12 de agosto. É o caso de Pedro Nolasco de Sá Marinho e Azevedo, viúvo de sua madrinha (já falecida) e ele próprio padrinho do soldado preso e acusado de crime punido com pena de morte na forca. Esse antigo morador na vila de Santo Amaro da Purificação, mas agora residente na cidade do Salvador, reconheceu-lhe a letra na carta deixada na igreja da Lapa e afirmou que ela correspondia à letra nas cartas que Luís Gonzaga enviara à madrinha, mas não as apresentou, nem elas foram requisitadas. Sob as cautelas que aqueles dias de repressão ensinavam, esclareceu que só concedia pouso e alimentos a Luís Gonzaga em respeito à memória de sua mulher, mas também demonstrou simpatia ao revelar que Luís Gonzaga "tinha suas manias e melancolias" e vivia muito só (32). Escrava de Pedro Nolasco, Emerenciana Francisca do Espirito Santo, a quem o soldado se referiu como "inimiga", depôs que "varias vezes ouvira proferir expressões atrevidas contra a religião" (...) "assim como contra a presente forma de governo, porque todos erão iguais" (...), vendo-o também escrevendo "alta noite, e com resguardo (cuidado), huns papeis compridos, tendo hum diante do outro" (33).

Outros que declararam também reconhecer a letra de Luís Gonzaga nos "papeis sediciozos" foram o cadete do $1^{\circ}$ Regimento de infantaria, dom Barnabé de Uzeda e Lima, e o filho de Pedro Nolasco, porta-bandeira do $1^{\circ}$ Regimento de artilharia, Francisco Nolasco de Sá Marinho e Azevedo (34). Ele declarou que o conhecia duplamente, do quartel e de casa ("assistia quase sempre em casa do pay") e confirmou "serem da propria letra do dito Luiz Gonzaga das Virgens" os papéis que lhe apresentaram apensos aos autos (35).

Tais testemunhos não podem ser desconhecidos, mas devem ser considerados nos limites das condições preconceituosas e repressivas sob as quais foram prestados. Nada obstante, o soldado Luís Gonzaga das Virgens negou sempre qualquer participação nos preparativos para "huma revolução" e na autoria e divulgação dos "papeis sediciozos". Além de negar tudo de que o acusavam, defendeu-se indicando sistematicamente como responsável outro que não ele: o mascate e cirurgião prático Manuel João ou João da Silva Norbona, cujo relacionamento terminou lamentando ao declarar que ele era o "homem que lhe meteu todos aquelles papeis para a sua perdição" (36).

Ao longo dos interrogatórios, 1798 e 1799, o soldado Luís Gonzaga das Virgens deu repetidas indicações para a identificação desse Manuel João ou João da Silva Norbona. Numa dessas disse que lhe entregara dinheiro e o fizera portador de um requerimento ao príncipe regente pedindo sua baixa da tropa paga. Foi na ocasião em que esse personagem ainda oculto 
viajou para Lisboa (1797), de onde regressou à Bahia meses depois. Também declarou que o encontrara no Terreiro de Jesus na véspera de sua prisão. Por conseguinte, ele estaria na cidade naqueles dias dos "papeis sediciozos" e dos convites para a reunião no Campo do Dique do Desterro.

Mas foi somente em fevereiro de 1799 que o desembargador Barbedo instalou a devassa para identificar o português João da Silva Norbona. Ouviu então 12 testemunhas, todos brancos: nove solteiros e três casados. Eram: seis caixeiros; um comerciante de tabaco e de livros que também exercia a profissão de carpinteiro; um comerciante de artigos marítimos; um droguista (vendedor de remédios); um vidraceiro e dois negociantes de tecidos. Três residiam no cais das Amarras, três no cais do Lixo, dois na rua Direita da Praia, os demais se distribuindo pela rua do Guindaste dos Padres do Carmo (um), beco do Guarda Prego (um), rua da Garapa (um) e rua do Passeio (um). Com a exceção única do que assinou em cruz, todos sabiam ler e escrever (37).

Residentes na Cidade Baixa (a Praia) nada sabiam de um mascate e cirurgião prático chamado Manuel João ou João da Silva Norbona. O soldado Luís Gonzaga dissera que esse desconhecido "tinha amizade" no comércio com Francisco Agostinho Gomes, Jacinto Dias Damásio “e outros muitos homens da Praia". Mas o desembargador Barbedo não os interrogou, nem aos "outros muitos", nem ao rico comerciante Francisco Agostinho Gomes, todavia um dos mais delatados para Lisboa pelo crime de francezia.

Por fim a devassa se reduziu à indicação de um Manuel João, mas esse Manuel João era Manuel João dos Reis, cirurgião do navio Careta.

Até mesmo quando as repetidas cobranças, enviadas de Lisboa pelo governo do príncipe regente dom João, forçaram novas prisões e novos interrogatórios (janeiro/março de 1799), o desembargador Barbedo não localizou João da Silva Norbona. No máximo ficou com as 12 testemunhas intimadas, uma das quais apontou esse Manuel João dos Reis, cirurgião do navio Careta e morador ao lado da Guarda da Praia.

Para cumprir a formalidade da devassa, o desembargador Barbedo o conduziu à presença de Luís Gonzaga, mas o soldado não o reconheceu como o João da Silva Norbona de quem falara nos interrogatórios. Até observou que esse era diferente do outro na estatura e na "cor da cara". Assim a devassa ficou concluída (38). E o soldado Luís Gonzaga das Virgens e Veiga terminou sendo o único acusado de ser o autor dos papéis de 12 de agosto e de todos os manuscritos e cópias apreendidas no porão da casa de Pedro Nolasco, no qual ele se abrigava "por piedade" desse padrinho. 
Condenado a morte na forca, três dias antes da execução foi levado para o Oratório do Tribunal da Relação. Mostrou ali sinais de perturbação mental, ele e o mestre alfaiate João de Deus do Nascimento. Informados do que se passava, os mordomos dos presos da Santa Casa de Misericórdia entregaram um requerimento solicitando providências médicas. Escreveram: "Os réus João de Deus do Nascimento e Luiz Gonzaga das Virgens se acham totalmente dementes, vazios e furiosos". O requerido foi concedido.

No dia 6 de novembro (morreriam a 8) foram examinados pelos bacharéis em Medicina Estevão Silveira e Menezes, Francisco José Novais Campos, Diogo Ribeiro Sanches e Inácio Francisco da Câmara Bittencourt, mais o "cirurgião de partido da Relação", Francisco Luís Reina. No caso do soldado Luís Gonzaga, atestaram que não haviam encontrado "gênero algum de indisposição, nem o menor sinal que se qualifique a moléstia que se lhe atribue". Também opinaram que o comportamento por ele apresentado era "ficção própria do seu gênio", nesse sentido acentuando que "só depois de ser notificada a sentença condenatória he que contrahio a presente demência que figura, e na qual nada há de realidade" (39).

Sem que ocorresse qualquer mudança na perturbação que apresentava, na manhã de 8 foi retirado do Oratório e amarrado, pés, mãos e tronco, num palanquim. E assim carregado para morrer na forca nova, erguida na praça da Piedade, onde o governo de dom Fernando José de Portugal a mandara construir com aparência ostentosa, para substituir a anterior, que certo dia amanheceu incendiada.

O carrasco já colocava a corda no pescoço de Luís Gonzaga, quando ele, parecendo acordar, indagou onde se encontrava, e escutando ou não resposta, pediu para confessar. Frei José do Monte Carmelo, carmelita descalço e prior do Convento e Igreja de Santa Teresa, que acompanhava os condenados desde a noite no Oratório, subiu rapidamente os degraus da forca e ouviu o soldado pedir que lhe abrisse os olhos, "pois estavam fechados, e pegados de modo q. os não podia abrir", pedindo também que o deixasse descer, para que fizesse "huma verdadeira confissão".

Sob a urgência do frade, o juiz de fora João da Costa Carneiro, que presidia as execuções, concedeu que ele o escutasse em confissão. Também reordenou as execuções, razão porque Manuel Faustino dos Santos Lira passou para o primeiro dos executados e Lucas Dantas do Amorim Torres para o segundo.

Único narrador desse episódio, frei José do Monte Carmelo escreveu que o soldado Luís Gonzaga das Virgens voltou-se de frente para os que assistiam as execuções e berrou palavras confusas, para as quais, todavia, ele 
encontrou sentido, conforme as transcreveu: "Sigão a ley do verdadeiro Deos, a Religião Catholica he a só e única verdadeira, tudo o mais he engano; quando eu a seguia, sem duvida alguma eu vivia bem, ainda q. pobre, (...) porém depois que dei ouvido a huns cadernos, a hum Voltaire, a hum Calvino, a hum Rousseau, deixei o q. não devera e por isso vim parar a este lugar" (40).

Pouco antes das três da tarde o soldado Luís Gonzaga das Virgens foi enforcado, seguindo-se a degola e o corte das mãos, que foram colocadas sobre um mastro (cabeça e mãos), ali mesmo na forca, a vista pública, para exemplo e aviso. Ficaram expostas cinco dias, sendo afinal retiradas por interferência dos Irmãos da Santa Casa de Misericórdia, que pediram ao governador permissão para as recolher e enterrar, não se sabe onde.

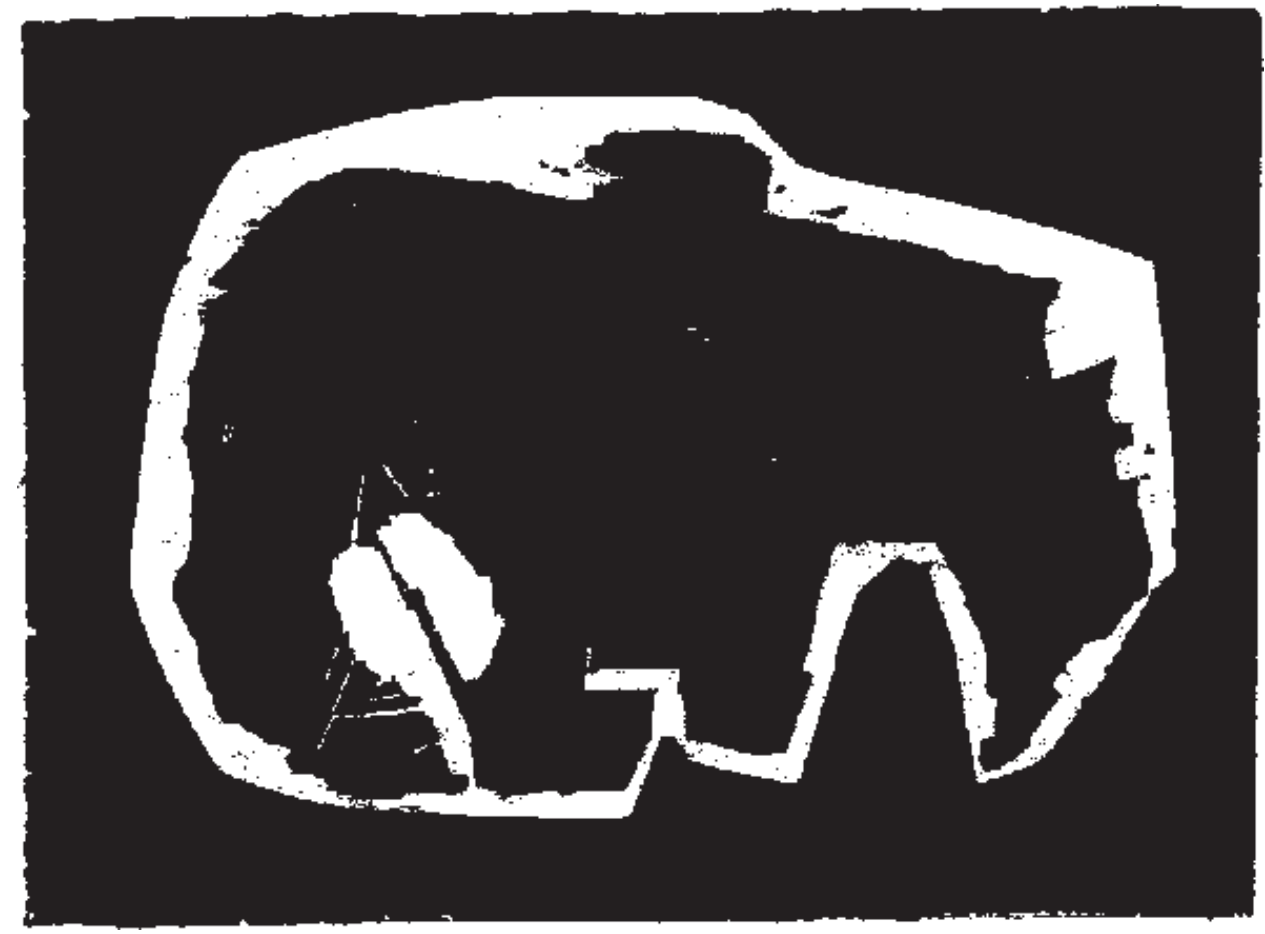

Os papéis encontrados

\section{com Luís Gonzaga Das Virgens}

A história dessa vida completa-se com os papéis encontrados no porão em que dormia. Para examiná-los, coloquei-os em duas ordens: papéis pessoais e papéis ideológicos, algo arbitrário, mas que pode fazer sentido, ao menos como tentativa de sistematizar uma documentação singular na 
História do Brasil, além de complexa e problemática. Toda ela é igualmente importante para nos aproximar do conhecimento e compreensão da ainda obscura sedição de 1798 na Bahia. E é indispensável para intuir os sentimentos e as idéias de um mártir brasileiro (ele o foi), o soldado mestiço Luís Gonzaga das Virgens.

As Series Temporais, Reflectivas e Noticiozas estão em dois cadernos, o primeiro mais extenso, todavia indicando ambos que o autor sabia ler e escrever e era pessoa tomada de curiosidade e inquietude, preocupado também com problemas práticos, como possíveis direitos numa herança e com a vida militar, na qual se considerava em situação especial por ser soldado voluntário.

É possível que essas anotações e lembranças tenham sido separadas no decurso das devassas, ou que fossem originalmente páginas soltas, nas quais ele ia escrevendo sem preocupação cronológica ou disciplina de assuntos. O segundo caderno, que é o menor, abre com o título e o nome do autor de um dos grandes poemas da literatura universal: Paraíso perdido, de John Milton. Mas não há transcrição de qualquer verso (41).

Como fizera antes, o soldado Luís Gonzaga também colocou sob a responsabilidade de João da Silva Norbona as notas e lembranças escritas nos cadernos das Series Temporais. Mas havia algumas que escapavam, de maneira evidente, dessa suposta autoria, a começar das que estão datadas de 1785 , anteriores, portanto, à sua primeira deserção e ao conhecimento do mascate e prático de cirurgia.

Após nove anos sem anotações, as Series voltam a 7 de maio de 1794, com os registros das nomeações dos bispos de Pernambuco, Maranhão e São Tomé; de três desembargadores para o Tribunal da Relação na Bahia; e de vários funcionários da administração colonial. Por certo que atento à sua situação de soldado insatisfeito, copiou as regras (ou exigências) para solicitar baixa da tropa paga e acentuou que o requerimento para dispensa só era permitido aos que ainda se encontrassem no primeiro ano de serviço, o que não era o seu caso.

Dessas notas em diante alternam-se as que registram a sua constante preocupação com religião. Em 1795 escreveu longa e instigante declaração, que transcrevo tomando a licença de colocar pontos e vírgulas inexistentes no original, todavia mantendo a mesma grafia: "De coração detesto a religião Franceza. Perdidos concidero aos da minha nação. Obediência não confeço a Calvino e Lutero. Por certo não tenho o sentido do Dialogo. Atribuo a delirio a doutrina de Lutero. Aborreço infinito ao pode- 
rozo Henrique. A missa e aos altares em geral venero. A todos os Christãos felicidade dezejo. Ao Vigr.o de Christo prostado reverencio. Estar Christo na hostia p.r gr.de verd.e tenho. A pureza de Maria por mais certo tenho. Ao Catholico povo ditozo fim dezejo" (42).

Como se nota, é um texto cheio de problemas, para os quais ainda não tenho explicações. E se é verdade que ele apenas copiava o que outros escreviam, falta encontrar ou identificar a fonte básica para as suas formulações, especialmente as referências a Calvino, Lutero e Henrique VIII. Estudiosa da história da religião reformada no Brasil, e a propósito deste trabalho, a doutora Marli Geralda Teixeira observa-me que o soldado Luís Gonzaga das Virgens percorreu os sertões de Pernambuco, Paraíba, Ceará e Rio Grande do Norte durante quatro ou cinco anos. Sendo essa área brasileira a que conheceu no século XVII longa ocupação (25 anos) de povos europeus ganhos pela religião reformada, não seria impossível que ainda se escutasse tradições orais calvinistas e luteranas caminhando por aquelas terras nos finais do século XVIII.

Mas há testemunhas que o escutaram dizer frases "anti-religiosas", ou seja: de restrições à igreja católica. Por exemplo, seu padrinho, Pedro Nolasco de Sá Marinho e Azevedo, declarou que o escutara falar "algumas expressões de irreligião" (43). Mariana Joaquina, mulher parda solteira, declarou que "certa ocasião" ouvira ele dizer palavras "contra a religião", o que motivou ser expulso de casa por sua madrinha, "para não mais tornar". A escrava Emerenciana Francisca do Espírito Santo, a quem ele considerava sua inimiga, testemunhou que não apenas o escutara "proferir expressões atrevidas contra a religião", como dizer "que desejava se acabasse tudo", nesse tudo incluindo "a presente forma de governo". Teria dito também que todos "herão iguais" (44).

Tais testemunhos valem nas circunstâncias da repressão, do preconceito e do conservadorismo da sociedade baiana. Não é de todo inverídico que o soldado Luís Gonzaga tenha dito frases de crítica e restrição à hierarquia eclesiástica, aos padres e aos frades, mas sem que isso incluísse a igreja católica. Pelo que se acompanha nas Series Temporais, após a sua "reforma" foi assíduo freqüentador de missas e fiel atento às orações e ladaínhas. $\mathrm{Na}$ véspera de sua prisão, assistiu e acompanhou missa na igreja do Senhor do Bonfim, na colina sagrada da devoção baiana, que ficava (fica) distante do centro da cidade do Salvador e só se podia alcançar a pé (45).

Há seguidas orações nas Series Temporais. Em dia não registrado de julho de 1797 caíram casas da ladeira da Misericórdia. Ele anotou. Em seguida colecionou várias orações impressas na publicação Horas Portu- 
guesas (46). A primeira é a que começa com a frase "Ó amantíssimo Deos, e Senhor de minha Alma...”. Continua com uma oração para antes da confissão; com a Súplica à Nossa Senhora para antes da confissão; com o Ato de Contrição etc. São igualmente de suas preocupações ou sentimentos religiosos as notas referentes ao opositor à cadeira de Teologia da Universidade de Coimbra, qualificador do Santo Ofício e examinador das três armas, frei Bento da Trindade, a quem desejou enviar um dos seus requerimentos; e a epístola de São Paulo aos romanos, da qual destacou o trecho: "Não vos entregueis aos excessos de comidas e bebidas, não às imundices vãs, mas vesti-vos das graças de Jesus Christo".

Foi o único dos quatro supliciados na forca que pediu para se confessar. A acreditar em frei José do Monte Carmelo, iniciou a confissão na sua noite de condenado, mas é particularmente instigante a parte gritada em público, ocasião em que teria dito que estava ali por ter ouvido "huns Cadernos, a hum Voltaire, a hum Calvino, a hum Rousseau", terminando por exclamar: "Sigão a lei do verdadeiro Deus, a Religião Catholica he a só e unica verdadeira" (47).

Destaco agora um dos mais notáveis documentos transcritos nos cadernos apreendidos com o soldado Luís Gonzaga das Virgens. São os cânones estabelecidos no Sínodo diocesano de Pistóia, realizado em 1786 sob o patrocínio do grande-duque da Toscania, Leopoldo, com o objetivo de preparar o grande conselho destinado a reformar a igreja católica naquela região da Itália. Adotados no Sínodo por unanimidade, na linha radical defendida por um movimento surgido na Alemanha nas últimas décadas do século XVIII, denominado febronismo, cuja motivação era a "nacionalização da igreja católica", foram recusados pela assembléia dos bispos toscanos reunida em Florença em 28 de agosto de 1787, para serem finalmente condenados pelo Vaticano (o Sínodo e os cânones) na bula Auctorum fidei, de 28 de agosto de 1794 (48).

Pode-se indagar por que esse documento interessou a um soldado brasileiro mestiço e neto de escrava, mesmo que ele tenha sido apenas o copista. Na impossibilidade de informação direta sobre os seus motivos, visto que não foram documentados, não se terá outra resposta a não ser a histórica, ou seja: a possibilidade da extensão do febronismo a Portugal, de onde teria alcançado o Brasil. Veja-se que ficaram possíveis pistas no bilhete de um Silva Lisboa, até agora não identificado (nada indica que o signatário fosse José da Silva Lisboa, o futuro visconde de Cairú) a Cipriano Barata: "Tenha cuidado com Frei José e Frei Francisco na disputa que manteem quanto ao querer cada qual ser chefe da Igreja". E nos "papeis sediciozos" mais contundentes em relação aos padres. Um deles exprime: "que seja punido com pena de morte natural para sempre todo aquelle e 
qualquer padre que no pulpito, conficionario, exortação por q.l q.r modo, forma, maneira etc. persuadir aos ignorantes e fanaticos o contrario da liberde" (49). Nada obstante, não insisto nessa linha em respeito a falta de documentação e a estudos específicos.

Outra boa parte das Series Temporais está dedicada à vida militar. Em dia e mês não declarados de 1794 registrou que o tenente Hermógenes Francisco de Aguillar Pantoja o dispensara da ronda no mar, dispensa que ele valorizou acentuando ter sido "a primeira que alcancei em ação de serviço" (50). Teria se desdobrado desde então um relacionamento de confiança entre eles, a ponto desse oficial lhe transmitir as críticas que fazia ao regime monárquico absolutista português e de lhe emprestar trechos do livro do conde de Volney, As Ruinas.

A 15 de agosto de 1795 o alferes granadeiro José Luís Teixeira lhe deu um atestado de boa conduta (51).

Anotou as licenças das guardas da Praia e da Ribeira e uma folga. É significativo que tenha copiado o alvará da rainha dona Maria I, de 14 de janeiro de 1791, regulando o tempo de serviço dos soldados nas tropas pagas. Era importante para ele porque diferenciava os soldados voluntários (era o seu caso) dos recrutas, e declarava, "em beneficio dos primeiros", que só teriam "obrigação de servir pelo espaço de seis anos, findo os quaes se lhes darão imediatamente as suas baixas” (52).

Deixou outras anotações de interesse. Escrita em 1795, uma dessas registra a morte na forca do rei da França, Luís XVI. Outra guardou a chegada da nau Conceição, trazendo a bordo os ex-governadores de Goa e Moçambique, generais Francisco da Cunha e Antonio Manuel de Melo, demitidos dos seus cargos e chamados a Lisboa para darem conta de suas administrações. Mas não é de menor significado ter copiado em 1796 um alvará "em forma de lei” da raínha dona Maria I, de 14 de abril de 1785, referente ao comportamento "irregular e desordenado" de governadores e capitães-gerais de Moçambique, rio de Sena e Sofala, por estabelecerem as suas próprias autoridades, entregarem a parentes "os ofícios da Justiça e Fazenda", aparecendo também como "senhores de importantes cabedaes, q. nos seus nomes e de terceiras pessoas remetião para fora, e empregavão no commercio" (53). Quem lia Moçambique, rio de Sena e Sofala, podia ler Brasil... Registrou também as preces dos fiéis ante a ameaça de novos desabamentos nas encostas da cidade em abril de 1795 .

É igualmente significativo o registro que fez do desembarque no porto da cidade do Salvador de dois enviados do rei do Daomé à Lisboa. Passa- 
vam por aquela cidade de conhecido movimento comercial com o reino do Daomé, troca de escravos por tecidos coloridos de algodão, fumo, e principalmente fuzis, munições e pólvora. E onde viviam homens e mulheres das nações Ioruba e Fon capturados pelos daomeanos e negociados no porto de Ajudá com os comerciantes portugueses de escravos, quase todos, senão todos, representados na cidade do Salvador por comerciantes portugueses, ou portugueses-brasileiros. Impressionou ao soldado Luís Gonzaga que eles fossem homenageados "com bandeiradas" e honras, mas que o governador não os recebesse como embaixadores e os isolasse no convento de São Francisco durante os dias em que estiveram na cidade (54). Também lhe impressionou a chegada de Lisboa (27 de maio de 1796) de um príncipe e embaixador do Daomé titulado Cavalheiro da Ordem de Cristo, para quem serviu de interprete um "homem pardo natural da Bahia" (55). Destacou que o príncipe era "hum homem preto"...

Na noite de 23 de outubro de 1795 escutou a mulher de "hum Vianna" espancar seus escravos. A $1^{\circ}$ de abril de 1796 registrou a saída de um comboio comandado pelo tenente-general Bernardo Ramires Esquivel. Nele estaria viajando para Lisboa João da Silva Norbona, portador de um requerimento seu pedindo para dar baixa do exército (56).

Relacionou 30 palavras, algumas com significados: "Absterger, alimpar; Accidente, perigo; Acétabulo, encaixe de osso; Acido, azedo; Acre, picante, aspero; Acrimónia, sabro, picante; Astringente, o q. aperta; Algêbra, o concerto de ossos; Deslocado e Algebrista, o q. os concerta; Sal ammoniaco; Antimonio, mineral; Aperiente, pa. obstar; Artetica; Artetico, o gotoso; Aspalatho, raiz de (palavra mutilada); Atrabelis; Attrativo, couza q. enca (mutilado); Attracto, encolhido nos nervos; Anon, i, n. q. figurão começando larga e estreita; Cono, i, gl. apinha, tambem amecca fra.; Pica, ce, f. g. à nêga ave, a malicia da mulher prenha; Fodio, is fodis, fossum; Cavar, ferir, picar; Clitoris, is, f. g. o pudendo feminino; Putana, a f. a puta mulher; Puta, a fig. Deoza puta (57). E copiou as definições de barbarismo, solecismo, sintaxe, elipse, zeugma, silepsie, síntese e pleonasmo (58).

São igualmente de leitura indispensável os requerimentos e petições apensos aos autos como de sua autoria. Muito ensinam para se ter alguma idéia de como era, agia, sentia e pensava o soldado Luís Gonzaga das Virgens. É o caso do requerimento que pretendeu enviar ao príncipe regente dom João pedindo para ser “ajudante” do $4^{\circ}$ Regimento de milícia, exatamente o dos pardos (59). Na impossibilidade de transcrevê-lo na integra, porque quebraria os limites deste trabalho, vou destacar apenas frases que parecem calcadas no Aviso de Petsburgo, documento que se encontra nos autos com várias rasuras e palavras riscadas, dessa forma parecendo de "hum 
habitante dessa colonia, por isso dirigido aos homens nella chamados de segunda Especie, habitantes dos paises torridos", no parecer do desembargador Francisco Sabino Alvares da Costa Pinto, que presidiu a devassa da reunião no Campo do Dique do Desterro (60).

É possível que não tenha passado de confusa minuta, mas isso não prejudica o raciocínio exposto. Começa destacando que a maioria dos soldados nas tropas pagas era de pardos, razão porque eram "onerados" com "todos os deveres do bélico trabalho", expondo suas vidas pelo bem do rei, do Estado e da Nação, sem merecerem acesso aos postos por causa da "diferença de cor", o que os colocava inferiores aos brancos "desde a adolescencia até perderem as forças, a saude e a propria vida". Ele guardava "a mágoa, a mágoa inconsolavel" de viver preterido somente por causa da cor. No seu caso pessoal, porém, via uma solução: ser removido para o $4^{\circ}$ Regimento de milícia, "por ser daqueles homens que lhe são iguaes", ou seja, de cor.

Documento impressionante, pelo que revela da discriminação de cor existente na administração e na sociedade colonial (o que havia na tropa paga não era exceção) também é expressivo pelos sentimentos contrastantes de orgulho e inferioridade que nele afloram. De orgulho, na afirmativa de servir em defesa do poder real, "do Estado e da Nação". E de inferioridade pelo travo amargo de reconhecer na sua condição de pardo obstáculo para qualquer pretensão. No requerimento a raínha, escreveu: “se o Suple não he digno de ser accessivel na graduação dos postos por ser pardo, paresse ser justo que elle, e todos os individuos da sua desgraçada classe, sejão extrahidos de huma compabilidade toda penoza, desgraçada e armada de calunias" (61).

Parece que as receitas farmacêuticas nas Series Temporais foram copiadas de livros do famoso médico inglês do século XVIII, John Pringle (está Pringles no original), e do químico, também inglês, Apleby. Este último é citado como autor da fórmula para transformar água salgada em água doce e do cálculo da velocidade do vento em um minuto. Na linha de sua atuação como cirurgião prático está o registro de ter aberto um pleuriz na filha de Inácio Brandão, Ana, feito que valorizou destacando que ela se encontrava no último mês de gravidez e se salvou (62).

E há o soneto laudatório ao governador. Por que o teria copiado? Sem possuir elementos para responder, limito-me a transcrevê-lo:

"Excelso Senhor, d'alto respeito

Similar a Theóndrico sois n'obrar 
A Bahia não cessa de exaltar

As virtudes que produz o vosso peito.

Com meus cantos, Senhor, menos delito

Em querer atributos promulgar

Pois meo intento só he explorar

Das vossas virtudes o effeito.

O Nó godio Real, sacro e pendente

Desatar não posso com honra e brio

Pois não sou de Corôa descendente.

Sim, que podeis nisso confio;

Ficando o Vosso Nome permanente

Pelo tropico adusto, e Cinto frio" (63).

Por último concluo que não se esgotam neste trabalho as questões e problemas sobre esse homem revoltado e rebelde; ser humano solitário, mas que deixou sinais de sua capacidade de estima no caso do laço de fita comprado para um companheiro de farda (não disse o nome, nem lhe foi perguntado) na manhã em que foi preso. Quanto à Fala de Boissy d'Anglas, o Orador dos Estados Gerais e Aviso de Petsburgo, nada há de novo para acrescentar ao notável trabalho de Katia Mattoso no seu livro Presença Francesa no Movimento Democrático Baiano de 1798. Quanto a circulação e leitura do livro As Ruinas na sedição de 1798 na Bahia (ao menos em um capítulo), ele está igualmente presente na história política de Portugal dos anos de 1780 e 1790 . E há tudo por fazer.

\section{Notas}

1 Arquivo Público do Estado da Bahia (APEB), arquivo colonial e provincial, "revolução dos alfaiates", maço 580; Anais do Arquivo Público do Estado da Bahia (AAPEB), v. 36, p. 461-476.

2 AAPEB, v. 36, p. 520-523, 545-550, 552, 580-583.

$3 I d .$, ib., p. 550-553.

4 Id., ib., p. 523-527, 529-544.

5 Id., ib., p. 498-495, 467, 472. 
$6 I d ., i b .$, p. $544-545$.

7 Id., ib., Fala de Boissy d'Anglas, p. 500-507; Orador dos Estados Gerais, p. 507517; Aviso de Petsburgo, p. 520; Gazeta de Lisboa, p. 517-519.

$8 I d ., i b .$, p. $567-571$.

9 Id., ib., p. 379. O original está no APEB, arq. col. e prov., maço 581.

10 Id., ib., p. 424-428.

11 Id., ib., p. 427.

12 Id., ib., p. 428-429, exame da assinatura de Luís Gonzaga; p. 579-580, interrogatório de 6 de março de 1799 . (Ver no maço 581 , o apenso $\mathrm{n}^{\circ} 5$, letra L: comparação da assinatura de Luís Gonzaga das Virgens no documento do Conselho de Guerra com as petições e requerimentos que teria escrito).

13 AAPEB, arq. col. e prov., Cartas ao Governo, Livro 155, p. 72v.

14 AAPEB, v. 36, p. 569.

15 Id., ib., p. 570, resposta 16B.

$16 I d .$, ib., p. 571, resposta $18 \mathrm{~B}$.

17 Anais da Biblioteca Nacional (ABN), v. 45, p. 78-79.

18 AAPEB, resposta à $l^{\text {a }}$ pergunta.

19 AAPEB, v. 36, p. 567, resposta 1B.

$20 \mathrm{ABN}$, v. 45 , p. $80-83$.

21 AAPEB, v. 36, p. 464.

22 Id., ib., p. 520-521.

23 Id., ib., p. 545.

24 Id., ib., p. 548-549. O teor do registro no Livro 67 está nas páginas 549-550; esclarece que Manuel Gomes Veiga tinha "varias dividas" a receber.

25 AAPEB, v. 36, p. 552.

$26 \mathrm{ABN}$, v. 45 , p. $46 ; 86-87$.

27 AAPEB, v. 36, p. 631.

28 Katia M. de Queirós Mattoso, A presença francesa no movimento democrático baiano de 1798, Itapuã, 1969; Bahia: 1798: os panfletos revolucionários; proposta de huma nova leitura, In: A revolução francesa e seu impacto na América Latina, Edusp, p. 341-350 (transcrição e estudo dos papéis de 12 de agosto). 
29 AAPEB, v. 36, p. 594.

$30 I d$., ib., p. 594-595, resposta à pergunta 22 (registro as declarações de Lucas Dantas com todas as reservas. Estão nos autos de uma devassa extremamente viciada e pode ser mais do escrivão do que do soldado-marceneiro, que todavia assinou o depoimento. Observo que ao fazer essas declarações ele ainda estava gravemente ferido na testa).

31 AAPEB, v. 36, p. 592, 593-594; v. 35, p. 14, 125 e 140; ABN, v. 45, p. 134.

32 AAPEB, v. 36, p. 389-390.

33 Id., ib., p. 391.

34 Id., ib., p. 393.

35 Id., ib., p. 399.

36 Id., ib., p. 576.

37 Id., ib., p. 583-384.

$38 I d .$, ib., p. 588.

$39 I d .$, ib., p. 487-488, 491-492.

40 Outra relação feita pelo p. frei José do Monte Carmelo, carmelita descalço, In: Luís Henrique Dias Tavares, História da sedição intentada na Babia em 1798, Pioneira/MEC, 1975. O original está no arquivo do IHGB, Noticia da Bahia, t. IV, Lata 402, manuscrito 69.

41 AAPEB, v. 36, p. 492.

$42 I d .$, ib., p. 464.

43 Id., ib., p. 390.

44 Id., ib., p. 391.

45 Id., ib., p. 570.

46 Id., ib., p. 523-524 (publicação católica, Horas portuguesas foi editada em Lisboa em 1786 pelo impressor da Real Mesa Censória, Antonio Rodrigues Galhardo. Está apensa aos autos da devassa presidida pelo desembargador Barbedo, mas incompleta).

47 Execução que se fez na cidade da Bahia no anno de 1799, manuscrito no arquivo do IHGB, Lata 402, documento 69, p. 319-323.

48 Encyclopedia Britanica, v. 17, P. to planting of trees, p. 964-965, Chicago- 
London-Toronto, 1953 (a palavra febronismo vem de Justinus Febronius, pseudônimo adotado pelo coadjutor do bispo de Treves, Johann Nikolaus von Hontheim, autor do livro que deu origem ao movimento).

49 AAPEB, v. 36, p. 374 (especula-se que algumas dessas regras foram cogitadas na época para uma possível igreja brasileira separada do Vaticano, cuja existência não está documentada).

50 Id., ib., p. 465.

51 Id., ib., p. 547.

52 Id., ib., p. 459.

53 Id., ib., p. 470-471.

$54 I d .$, ib., p. 465.

55 Id., ib., p. 476.

56 Id., ib., p. 528.

57 Id., ib., p. 467 e 472.

58 Id., ib., p. 493.

59 Id., ib., p. 582-583.

$60 I d .$, ib., p. 577.

$61 I d$., ib., p. 522. O grifo é meu.

$62 I d .$, ib., p. 520.

63 Id., ib., p. 544-545. Chamo atenção para o primeiro terceto.

RESUMO : O SOLDADO Luís Gonzaga das Virgens foi um dos quatro supliciados em 8 de novembro de 1799 (enforcado e esquartejado) na praça da Piedade, cidade de Salvador, Bahia. Distingue-se dos outros três (Lucas Dantas de Amorim Tores, Manuel Faustino dos Santos Lira e João de Deus do Nascimento) por ser mais letrado. Pelo lado materno, descendia de português e crioula; pelo lado paterno, de crioulo. Era católico praticante. Sentiu e expressou o sentimento de revolta contra o preconceito de cor dominante no seu tempo.

ABSTRACT: PTE LUÍs Gonzaga das Virgens was one of four people executed (hanged and quartered) on Nov. 8, 1799, in the Brazilian city of Salvador, Bahia. Among the three others (Lucas Dantas de Amorim Tores, Manuel Faustino dos Santos 
Lira and João de Deus do Nascimento) he stood out for his higher education level. On his mother's side, he was a descendant of Portuguese and creoles; on his father's side, of creoles. A practicing Catholic, he nursed and made manifest a rebellious feeling against the predominant color prejudice of his day.

Luis Henrique Dias Tavaresé professor titular emérito da Universidade Federal da Bahia (UFBa) e pós-doutorado na Universidade de Londres. É autor de 23 livros, dentre os quais: História da Bahia, Comércio proibido de escravos, O senhor capitão e $A$ beróica morte do combativo guerreiro.

Uma primeira versão deste trabalho foi publicada nos Anais da XII Reunião da Sociedade Brasileira de Pesquisa Histórica, Curitiba, 1993. Agora aparece totalmente revisto e modificado, resultado de novas leituras da documentação no período de 1996-1997. Este texto foi escrito na cidade do Salvador em janeiro de 1998. Não é definitivo.

As ilustrações foram feitas pelo artista plástico Alberto Martins a pedido da revista ESTUDOS AVANÇADOS. Com base na leitura do texto ele desenvolveu uma série de xilogravuras. A primeira corresponde à "deserção de Luiz Gonzaga", a 2 a "contatos

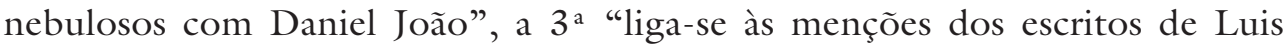
Gonzaga”, a 4a "à afirmação das 'idéias próprias' de Luiz Gonzaga” e a 5a "refere-se ao desfecho reservado ao soldado Luis Gonzaga". 